\title{
Wright's
}

\section{is the 'rule'}

\author{
for the
}

\section{Toilet and}

\section{Nursery}

\section{because...}

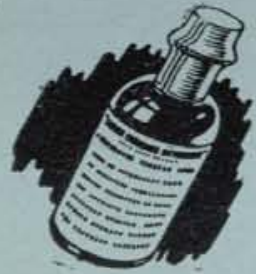

Wright's Coal Tar Soap incorporates in its basic formula the active principle Liquor Carbonis Detergens. This unique preparation is abstracted from Tar oils and isolates the known antiseptic and antipruritic agents contained in these oils from the inert substances and irritants of no therapeutic value. Wright's Liquor Carbonis Detergens has, in the 80 years since it was first introduced, achieved a high place in dermatological practice; and today is prescribed by many leading skin specialists and specified in their authoritative works of reference. The use of Liquor Carbonis Detergens as the antiseptic medium makes Wright's Coal Tar Soap safe for everyday Toilet and Nursery use and soothing to the tenderest skin.

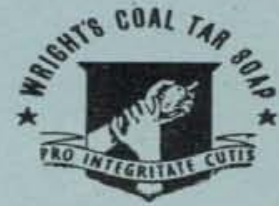

WRIGHT, LAYMAN \& UMNEY LTD · SOUTHWARK · LONDON · S.E.I · HOP 2315 


\section{O N T E N T S \\ (All rights reserved)}

PAGE

WoOlf, BARnet and WATERHoUSE, JoHn. Studies on infant mortality. Part I. Influence of social conditions in county boroughs of England and Wales. (With 8 Figures in the Text) . . . . . .

Kuteneberger-Nobel, Emmy. Changes in the nuelear strueture of bacteria, particularly during spore formation. (With Plates 2-4 and 3 Figures in the Text) . . . . . . . . . .

TAYLOR, C. B. The effect of temperature of incubation on the results of tests for differentiating species of coliform bacteria . . . .

Berger, F. M. A new non-mannite-fermenting dysentery organism of the Flexner group .

Gelt, P. G. H., Hoвbs, Betry C. and Aluison, V. D. An outbreak of water-borne typhoid investigated by bacteriophage typing and 'selective' sewage examination. (With 1 Figure in the Text) . . .

Wrison, J. F. Agglutination tests in the diagnosis of enteric fever in the inoeulated

Barr, Molite and Glenny, A. T. Some practical applications of immunological principles. (With 5 Figures in the Text). . . . .

DAY, H. B. Studies on immunization by a species antigen. III. The presence of an anti-immunity factor in Pneumococcus . . .

The Journal of Hygiene is now issued irregularly. A volume is issued in paper covers at the following net prices:

Volumes I-III (1901-3). 17s. 6d. net per volume.

Volumes IV-XVI (1904-18), excepting Vol. VI, no. 4, Plague number. 25s. net per volume.

Volume XVII (1918). 31s, net.

Volumes XVIII-XXXI (1919-31). 42s. net per volume.

Volumes XXXII-XXXVII (1932-37). 47s. 6d. net per volume.

Volumes XXXVIII-XLIII (1938-44). 75s. net per volume.

Quotations can be given for buckram binding cases, also for bound copies of back volumes.

Papers for publication should be sent to Dr G. S. Graham-Smith, Dept. of Pathology, Tennis Court Road, Cambridge. Other communications should be addressed to the University Press, Cambridge.

Papers forwarded to the Editor for publication are understood to be offered to The Journal of Hygiene alone, unless the contrary is stated.

Contributors receive twenty copies of their papers free. Twenty-five additional copies may be had at cost price: these should be ordered when the final proof is returned.

The subscription price is $£ 3.15 s$. 0 d. per volume (post-free), payable in advance; single numbers $16 s$. $0 d$. net. Subscriptions may be sent to any Bookseller, or to The Cambridge University Press, Bentley House, 200 Euston Road, London, N.W. 1.

The Cambridge University Press has appointed the University of Chicago Press agents for the sale of The Journal of Hygiene in the United States of America.

PRINTED IN GREAT BRTTAIN BY WALTER LEWIS, M.A., AT THE UNIVERSITY PRESS, CAMBRIDGE 